\title{
What Is Wrong with Selling Citizenship? It Corrupts Democracy!
}

\author{
Rainer Bauböck
}

Like the Roman god Janus, whose head was displayed above city gates, citizenship has two faces: one looks outwards, the other one inwards. The external face turns to other states and demands that they recognise the country's passport as well as to citizens living abroad whom it promises the right to return and diplomatic protection. The internal face speaks to citizens as members of a democratic community. It tells them that, in spite of their different interests and identities, they are equal as individuals and collectively govern themselves through their right to vote. The two faces belong to the same head, but sometimes the stories that they tell become dangerously disconnected.

The European Union has strongly increased the external value of its member states' citizenships. It has expanded the right to return into freedom of movement throughout the Union. The EU passport is, moreover, a key that opens the doors of a large number of third countries for visa-free entry. Finally, EU citizenship offers now also diplomatic protection by other member states to EU nationals residing in third countries. When selling its passport for $€ 650,000$ to non-resident foreigners, Malta intends to cash in on this European added value of its external citizenship. It is not hard to understand why this irritates EU institutions and other member states. Malta behaves like a member of a cooperative that sells membership to outsiders at a price that in no way reflects her own contributions.

Beyond the obvious unfairness in the division of monetary gains from the value of EU citizenship, member states also have reasons to be concerned about any one of them naturalising persons born and residing abroad without genuine links to the country. As Shachar and Dzankic point out, these people are likely to use their passports for other purposes than a 'return' to the state whose citizenship they have obtained. In this respect, Italy, Hungary and Romania, whose ethnic citizenship policies have created hundreds of thousands of new EU citizens abroad, are worse sinners than Malta. What the Maltese and similar programmes do is to transform an inherited privilege of co-ethnic populations residing abroad into a global commodity. 
This makes it quite natural to consider the external value of citizenship from a global perspective, as Spiro, Armstrong and Barbulescu do in different ways. Spiro regards the sale of citizenship as yet another symptom of its inevitable decline due to globalisation, alongside the increasing toleration of dual citizenship, as he has argued previously. While the instrumental value of citizenship of an EU member state for transnationally mobile populations has increased, citizenship as a 'sacred bond' between an individual and a state has unravelled. Armstrong and Barbulescu look instead at citizenship through a lens of global (in)justice and conclude that the sale of EU passports is merely one instance - and not the most significant one - of how citizenship policies 'both feed off, and make it harder to tackle, underlying global inequalities.' This echoes Shachar's initial comment that we should be equally critical of the comparatively rare practice of putting up citizenship for sale and of 'granting citizenship according to nothing but the fortuitous and arbitrary circumstances of station of birth'.

I suggest that it is useful to consider the external and internal perspectives separately. From a global perspective, birthright citizenship may indeed look suspiciously arbitrary, although I would not regard it as a cause of global injustice. To see why, consider the EU as a regional model for a potentially more just global regime. In the EU, free movement and access to opportunities elsewhere is linked to citizenship in a member state, which is again based on birthright in each of these states. So it seems misconceived to point to birthright citizenship as the culprit that causes global social inequalities instead of blaming unequal resources, global economic governance and immigration control.

Once we walk through the city gates and listen to the voice of Janus from the other side, our critique of citizenship for sale will change quite radically. Barbulescu asks rhetorically: 'If all countries were equal in living conditions would the scheme be objectionable?' From inside a democratic community, the answer to this question must be an emphatic yes! To understand why, let us focus for a moment on the core political right of citizenship, the franchise in democratic elections. Isn't it objectionable to sell the right to vote to outsiders? Suppose that, in reaction to critiques by the other EU states, Malta decides to sell the franchise in its national elections rather than its passports. The price it could achieve would be of course much lower, but would it be all right to do so? Let me hasten to say that Malta and Cyprus are among the very few European states that currently do not allow their citizens residing abroad to cast their vote in national elections. So while investors can get citizenship without taking up residence, they will need to 
move to these island states in order to vote. Yet this seems a fortuitous coincidence rather than a policy design.

The corruptive political influence of linking citizenship to investment can be nicely illustrated by the story of Frank Stronach, a billionaire of Austrian origins who made his fortune in Canada. Under Austrian law, Stronach lost his Austrian citizenship upon becoming a Canadian citizen. When he established European headquarters of his company in Austria, he was granted citizenship under a special provision that requires neither residence nor renunciation of another nationality and that has also been used to naturalise Russian oligarchs alongside famous artists and sportsmen on grounds of "extra-ordinary achievements in the interest of the republic". Once he had retrieved his Austrian citizenship, Stronach started buying political influence by recruiting former politicians for his company. In 2012, Stronach bought himself also a political party that he called 'Team Stronach' and ran an expensive election campaign. He made a bit of a fool of himself in TV debates and got fewer votes than expected, but there is now a party in the Austrian Parliament established by and named after an investor-citizen. Maybe Stronach should not have lost Austrian citizenship in the first place. But the way in which he was able to reacquire it through his investment opened the doors widely to his subsequent corruptive influence on Austrian politics.

Of course, citizenship-from-the-inside is not only about voting and being elected. I am not so sure that it requires loving your country, as Dzankic suggests. But it certainly means being treated as an equal member and treating others as equal members of a political community. Magni Berton also looks at citizenship from the inside but does not emphasize sufficiently equality among citizens. He is right that the state invests into citizens and citizens invest into each other. But citizenship status and rights must not be proportional to the investments citizens make, or even conditional on such investments.

Voting rights provide again the test. Throughout much of the 19th century, the franchise was still a class privilege. 'No taxation without representation' also meant 'no representation without taxation.' Only those who contributed to the state coffers had a right to be represented in the making of laws. This is no longer our vision of democracy. True, democratic societies have hardly become more egalitarian since then and, as Stronach's example demonstrates, wealth can rather shamelessly buy influence in politics. Turning the status of citizenship itself into a marketable commodity would mean more than this. It would tear down a wall of protection that keeps 
social class from becoming, once again, a formal marker of inequality of citizenship rights and status. One could object that, once they are citizens, the votes of foreign investors will not formally count for more than everyone else's. But it seems quite naïve to think that a club that starts to sell its membership at a price that only the ultra-rich can afford will keep treating its poorer members as equals.

Barbulescu makes an interesting point that 'citizenship-by-investment largely contradicts the very recent efforts of states to re-substantiate citizenship through tests and integration requirements.' It seems indeed inconsistent to waive integration conditions for investors while at the same time insisting that citizenship can only be granted to foreign immigrants as a reward for their individual integration efforts. Yet from a democratic perspective both of these policies represent the same worrying trend: they link access to citizenship once again to social class. While income tests for naturalisation have an explicit class bias, knowledge tests have an implicit one, since education and the capacity to learn for tests is strongly related to social class.

But isn't the way citizenship is obtained anyhow morally arbitrary? Why should those who have citizen parents or who have been born in the state's territory have a stronger moral claim to citizenship than foreigners who are ready to pay or invest? Why should even long-term residence count, if those who can naturalise on that basis have been pre-selected by immigration controls that do not offer the same chances to the rest of the world's population? These may be relevant questions from a global justice perspective. From an internal democratic perspective, they are wrongly asked. Long-term residence is what makes immigrants' relation to the political community equal to that of native citizens in the relevant sense and is therefore not at all an arbitrary criterion for access to citizenship as membership in a particular polity. The same can be said for ius soli and ius sanguinis. Instead of giving citizens specific privileges based on a claim to land or to parental inheritance, these birthright rules make them equal amongst each other by referring to the circumstances of birth that they share in common, be it birth in a territory or to citizen parents. Moreover, by providing individuals with citizenship at birth and for life, states protect them in a much stronger way than clubs who select their members based on present members' interests in their contributions or in choosing new ones who are like themselves. Selecting future citizens on grounds of either investment or income and knowledge tests departs fundamentally from the egalitarian thrust that underlies rules of birthright citizenship as well as residence-based naturalisation. 
So how should the EU and its member states react to citizenship-forinvestors laws? They should protest that these policies undermine solidarity between member states, but they should also protest against the internal hollowing out of democratic standards. As a union of democracies, the EU must be concerned when democracy is corrupted by the rule of money in any of its member states. Bribing officials is not the only way in which this happens. Selling citizenship is, too.

Open Access This chapter is licensed under the terms of the Creative Commons Attribution 4.0 International License (http://creativecommons.org/licenses/by/4.0/), which permits use, sharing, adaptation, distribution and reproduction in any medium or format, as long as you give appropriate credit to the original author(s) and the source, provide a link to the Creative Commons license and indicate if changes were made.

The images or other third party material in this chapter are included in the chapter's Creative Commons license, unless indicated otherwise in a credit line to the material. If material is not included in the chapter's Creative Commons license and your intended use is not permitted by statutory regulation or exceeds the permitted use, you will need to obtain permission directly from the copyright holder.

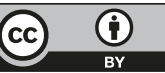

